\title{
SISTEM PENDUKUNG KEPUTUSAN UNTUK DISPENSASI PEMBAYARAN UANG KULIAH
}

\author{
Poningsih ${ }^{1}$, Sundari Retno Andani ${ }^{2}$ \\ AMIK Tunas Bangsa Pematangsiantar, AMIK Tunas Bangsa Pematangsiantar \\ Jl. Jendral Sudirman Blok A No. 1-3 Pematangsiantar, (0622) 22431 \\ poningsih@amiktunasbangsa.ac.id, sundari.ra@amiktunasbangsa.ac.id
}

\begin{abstract}
STIKOM Tunas Bangsa give facility to some students in tuition payment to the underprivileged students in economic but they achieve. For the convenience, it must suitable with applicable criteria established by the Institution. Because of the large number of students who apply for the tuition free dispensation was very much, it is necessary to build a decision support system to give a decision or recommendation associated with the tuition payment dispensation. This decision support system use fuzzy logic that will help STIKOM Tunas Bangsa Institution in determining who is eligible to receive a tuition free dispensation as well as a large percentage of tuition free delays. The criteria that established in this case study was the large of parents income, the number of parental dependent, the number of sibling. Not all who apply for dispensation will be accepted, but only those who meet the criteria will be accepted.
\end{abstract}

Keyword: Fuzzy Logic, Fuzzy Inference System, Dispensation of tuition payments

\begin{abstract}
Abstrak
STIKOM Tunas Bangsa memberikan kemudahan bagi beberapa mahasiswa/I dalam pembayaran uang kuliah bagi mahasiswa/I yang keadaan ekonominya kurang mampu namun dia berprestasi. Untuk mendapatkan kemudahan atau dispensasi tersebut maka mahasiswa harus memenuhi beberapa persyaratan/criteria yang berlaku yang telah ditetapkan oleh pihak Institusi. Oleh karena jumlah mahsiswa/I yang mengajukan permohonan dispensasi pembayaran uang kuliah tersebut sangat banyak, maka perlu dibangun sebuah sistem pendukung keputusan untuk memberikan sebuah keputusan atau rekomendasi terkait dengan penundaan/dispensasi pembayaran uang kuliah tersebut. Sistem pendukung keputusan ini menggunakan logika fuzzy yang akan membantu pihak STIKOM Tunas Bangsadalam menentukan siapa saja yang layak/berhak untuk mendapatkan dispensasi pembayaran uang kuliah serta besar persentase penundaan pembayaran uang kuliah tersebut. Criteria-kriteria yang ditetapkan dalam studi kasus ini adalah besar penghasilan orang tua, jumlah tanggungan orang tua, jumlah saudara kandung. Tidak semua yang mengajukan permohonan dispensasi akan diterima, melainkan hanya yang memenuhi syarat/criteria saja yang akan diterima.
\end{abstract}

Kata kunci: Logika Fuzzy, Sistem Inferensi Fuzzy, Dispensasi pembayaran uang kuliah

\section{PENDAHULUAN}

Perguruan Tinggi adalah perusahaan yang bergerak di bidang jasa, dengan produk utamanya adalah layanan pendidikan. Perguruan Tinggi adalah perusahaan yang mengutamakan pelayanan dibandingkan keuntungan semata[1]. Seiring dengan perkembangan yang ada saat ini, jika dilihat dari segi sosial, ekonomi, budaya dan masyarakat, Perguruan Tinggi tidak hanya menjadi penghasil sumber daya manusia yang berpendidikan, tetapi juga harus menjadi sumber penelitian dan pengembangan, sumber ilmu pengetahuan. Tetapi itu semua tidak terlepas dari peran sebuah Perguruan Tinggi itu sendiri yakni sebagai penyedia jasa pendidikan [2]. 
STIKOM Tunas Bangsa sebagai salah satu Perguruan Tinggi Swasta di Pematangsiantar yang memberikan kemudahan/keringanan terhadap pembayaran uang kuliah kepada mahasiswa/I yang kurang mampu. Penundaan atau dispensasi yang diberikan dari pihak manajemen kepada mahasiswa/I STIKOM Tunas bangsa terdiri dari 3 kriteria yaitu, dispensasi 50\% dari uang kuliah (Tunda50), dispensasi 80\% dari uang kuliah (Tunda80) dan dispensasi 100\% dari uang kuliah (Tunda100). Penelitian ini dibuat bertujuan agar pemberian dispensasi terhadap cicilan uang kuliah yang diberikan kepada mahasiswa/I bisa berlaku adil dan prosedural. Tidak semata-mata menggunakan insting (perasaan). Hal ini pun bisa lebih efektif untuk penambilan keputusan kedepannya terkait dengan pemberian ijin dispensasi pembayaran uang kuliah[3]. Adapun perumusan masalahnya adalah sebagai berikut:

1. Pada saat jatuh tempo cicilan, banyak mahasiswa yang menunda pembayaran cicilan uang kuliah

2. Tidak jarang keputusan yang diambil oleh pihak manajemen dalam memberikan dispensasi uang kuliah adalah salah satunya dengan menggunakan insting (perasaan) kasihan kepada mahasiswa

3. Dengan menggunakan insting (perasaan) tersbut, terkadang keputusan terkesan kurang adil dan kurang prosedural

4. Bagian keuangan (dalam hal ini bagian dispensasi) mengalami kesulitan dalam menentukan siapa mahasiswa yang berhak mendapat dispensasi keterlambatan pembayaran uang kuliah dikarenakan berbagai alasan yang diajukan oleh si mahasiswa/i

\section{METODOLOGI PENELITIAN}

\subsection{Sistem Pendukung keputusan}

Pada sistem pendukung keputusan yang dalam bahasa Inggris disebut dengan Decision Support System atau yang disingkat dengan DSS adalah bagian dari sistem informasi berbasis komputer termasuk sistem berbasis pengetahuan (manajemen pengetahuan) yang dipakai untuk mendukung pengambilan keputusan dalam suatu organisasi atau perusahaan[4]. Dalam pemrosesannya, sistem pendukung keputusan dapat menggunakan bantuan dari sistem lain seperti artificial intelligence, expert system, fuzzy logic, dll [1][5].

\subsection{Logika Fuzzy}

Logika fuzzy merupakan metode yang tepat untuk memetakan suatu ruang input ke dalam suatu ruang output. Fuzziness dapat diartikan sebagai logika samar yang berkenaan dengan semantic dari suatu kejadian, fenomena atau pernyataan itu sendiri [6].

\subsection{Tahapan dan Lokasi Penelitian}

Pada Penelitian ini akan dilakukan dalam 2 tahapan, yakni tahap-tahap sebagai berikut: 
1. Analisa Kebutuhan

Dalam tahap ini yang dilakukan adalah menganalisa apa saja kebutuhan baik software maupun hardware yang diperlukan untuk mendukung penyelesaian masalah yang ada.

2. Identifikasi Masalah

Proses ini dilakukan untuk mengetahui permasalahan yang dihadapi dan bagaimana cara menyelesaikannya. Proses mengidentifikasi masalah dilakukan untuk mengetahui sejauh mana permasalahan yang ditemukan sehingga diperoleh sumber masalah yang jelas. Kemudian berangkat dari permasalahan tersebut di atas, akan diberikan sebuah solusi atau jalan keluar sehingga masalah-masalah yang muncul yang menjadi kendala bisa di atasi dan diharapkan bisa meminimalisir terjadinya kesalahan atau error yang telah terjadi sebelumnya.

\subsection{Bahan}

Didalam penelitian ini digunakan software matlab 6.1 sebagai aplikasi penerapan dan implementasi penghitungan logika fuzzy.

\subsection{Studi Literatur}

Studi literatur dilakukan setelah proses identifikasi masalah. Studi literatur digunakan untuk mendapatkan pengetahuan dari referensi penelitian yang mendukung penelitian ini dan yang sudah dipublish yaitu bagaimana mendapatkan informasi seputar pembayaran cicilan uang kuliah di STIKOM Tunas Bangsa Pematangsiantar. Studi literatur ini dilakukan dengan mencari sumbersumber atau referensi yang berasal dari jurnal dan buku-buku yang berkaitan dengan permasalahan yang relevan dengan masalah tersebut.

\section{HASIL DAN PEMBAHASAN}

Pada tahapana ini akan ditentukan besarnya ijin dispensasi pembayaran uang kuliah dengan menggunakan Fuzzy Logic Toolbox pada Matlab. Metode FIS yang digunakan adalah metode Mamdani dimana fungsi implikasi yang digunakan adalah min [4].

\section{a. Bagan/skema himpunan fuzzy}

Pada bagan di dapat dilihat bahwa variabel yang digunakan sebagai input diberikannnya sebuah dispensasi uang kuliah adalah sebanyak 3 variabel, yaitu: (1) penghasilan orang tua (2) jumlah saudara kandung, dan (3) jumlah tanggungan orangtua. Dari ke 3 faktor tersebut di atas maka dilakukan defuzzyfikasi dengan metode mamdani untuk memdapatkan grafik dispensasi pembayaran uang kuliah. 


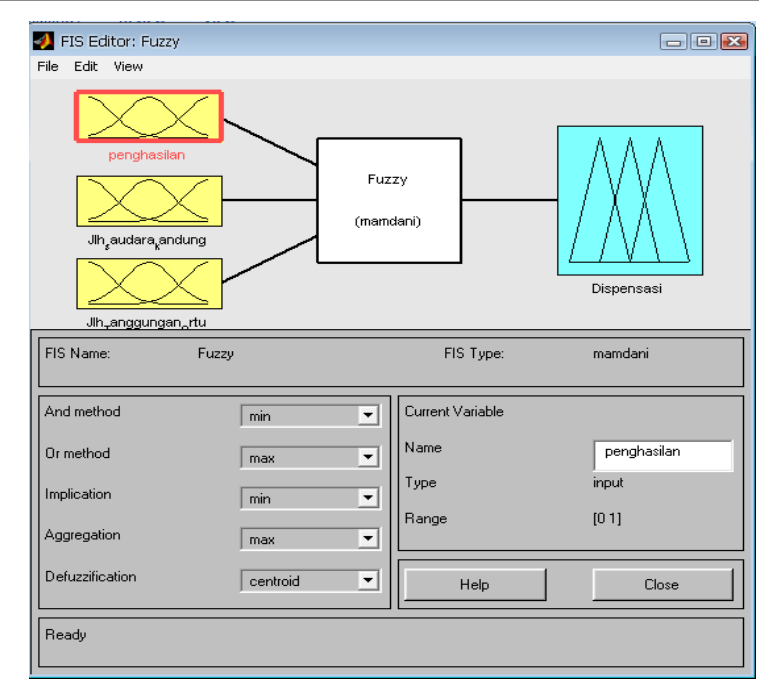

Gambar 1. Bagan/Skema himpunan fuzzy

\section{b. Penentuan Fungsi Keanggotaan}

Dari data mahasiswa maka ditentukan fungsi keanggotaan (Membership Function) untuk masing-masing atribut dengan himpunannya adalah sebagai berikut:

Tabel 1. Himpunan Fuzzy

\begin{tabular}{|c|c|c|c|c|c|}
\hline Fungsi & Variabel & $\begin{array}{c}\text { Nama } \\
\text { himpunan fuzzy }\end{array}$ & $\begin{array}{c}\text { semesta } \\
\text { pembicaraan }\end{array}$ & domain & jlh penghasilan \\
\hline \multirow{9}{*}{ Input } & \multirow{3}{*}{ Penghasilan } & sedikit & \multirow{3}{*}{$0-1$} & $0-0.5$ & $300000-800000$ \\
\hline & & sedang & & $0.25-0.75$ & $500000-1700000$ \\
\hline & & banyak & & $0.5-1$ & $1500000-3000000$ \\
\hline & \multirow{3}{*}{ Jumlah saudara kandung } & sedikit & \multirow{3}{*}{$1-9$} & $1-5$ & \\
\hline & & sedang & & $3-6$ & \\
\hline & & banyak & & $4-9$ & \\
\hline & \multirow{3}{*}{ Jumlah Tanggungan Orang Tua } & sedikit & \multirow{3}{*}{$2-9$} & $2-4$ & \\
\hline & & sedang & & $3-7$ & \\
\hline & & banyak & & $4-9$ & \\
\hline \multirow{3}{*}{ Output } & \multirow{3}{*}{ Dispensasi } & tunda 50 & \multirow{3}{*}{$20-100 \%$} & $20-50$ & \\
\hline & & tunda 80 & & $40-80$ & \\
\hline & & tunda 100 & & $60-100$ & \\
\hline
\end{tabular}

Pada gambar di atas dapat dilihat bahwa setiap variabel mempunyai himpunan fuzzy yang sama, namun berbeda pada semesta pembicaraan dan domain nya. Himpunan fuzzy pada setiap variabel memiliki nilai yang sama yaitu, sedikit, sedang dan banyak. Adapun klasifikasinya adalah sebagai berikut: Untuk variabel penghasilan mempunyai himpunan fuzzy sedikit dengan semesta pembicaraan 0-1 dengan domain 0-0.5, himpunan fuzzy sedang dengan semesta pembicaraan 0-1 dengan domain 0.25-0.75, himpunan fuzzy banyak dengan semesta pembicaraan 0-1 dengan domain 0.5-1. Untuk variabel jumlah saudara kandung mempunyai himpunan fuzzy sedikit dengan semesta pembicaraan 1-9 dengan domain 1-5, himpunan fuzzy sedang dengan semesta pembicaraan 1-9 dengan domain 3-6, himpunan fuzzy banyak dengan semesta pembicaraan 1-9 
dengan domain 4-9. Untuk variabel jumlah tanggungan orang tua mempunyai himpunan fuzzy sedikit dengan semesta pembicaraan 2-9 dengan domain 2-4, himpunan fuzzy sedang dengan semesta pembicaraan 2-9 dengan domain 3-7, himpunan fuzzy banyak dengan semesta pembicaraan 2-9 dengan domain 4-9. Kemudian untuk variabel outputnya yaitu dispensasi dengan 3 kriteria himpunan fuzzy yakni, tunda 50 dengan semesta pembicaraan $20-100 \%$ dengan domain 20 50, himpunan fuzzy tunda 80 dengan semesta pembicaraan $20-100 \%$ dengan domain 40-80, himpunan fuzzy tunda 100 dengan semesta pembicaraan $20-100 \%$ dengan domain 60-100.

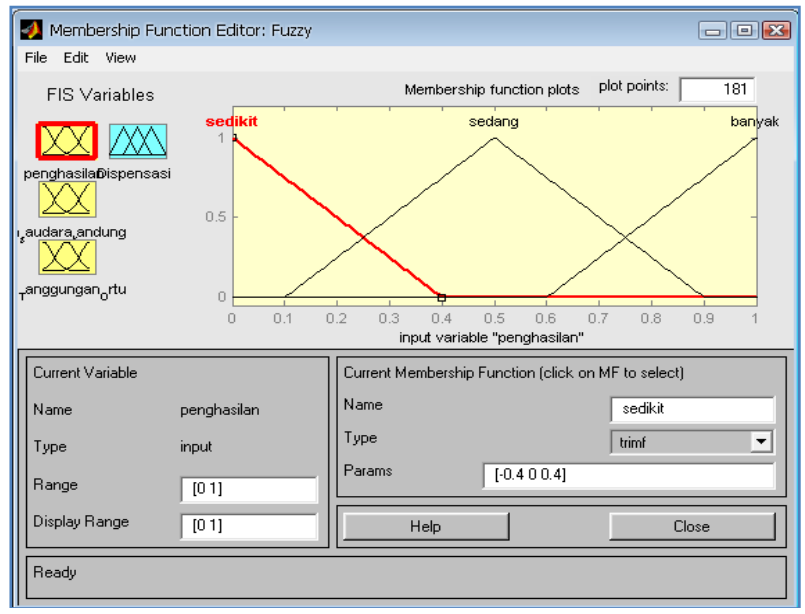

Gambar 2. Fungsi Keanggotaan Input Variabel Penghasilan

Pada gambar di atas dapat dilihat bahwa untuk variabel penghasilan mempunyai 3 fungsi keanggotaan yakni sedikit, sedang dan banyak. Dimana jika dilihat dari grafik, maka ketiga fungsi keanggotaan tersebut mempunyai nilai $\mathrm{x}$ dan y yang berbeda-beda namun antara satu fungsi keanggotaan denga fungsi keanggotaan yang lain mempunyai bagian range yang sama sehingga grafik menunjukkan adanya perpotongan diantara ke 3 fungsi keanggotaan tersebut.

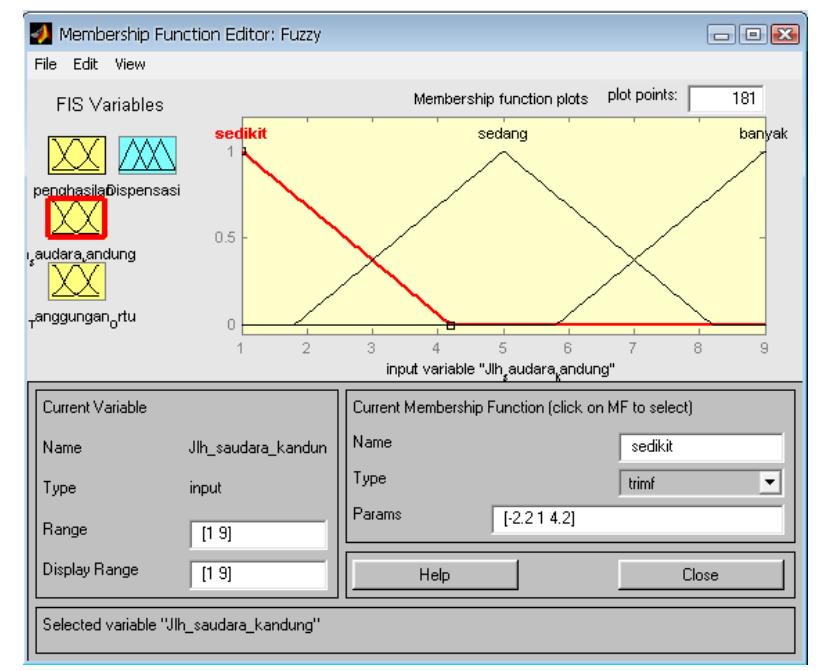

Gambar 3. Fungsi Keanggotaan Input Variabel Jumlah Saudara Kandung 
Pada gambar di atas dapat dilihat bahwa untuk variabel jumlah saudara kandung mempunyai 3 fungsi keanggotaan yakni sedikit, sedang dan banyak. Dimana jika dilihat dari grafik, maka ketiga fungsi keanggotaan tersebut mempunyai nilai $\mathrm{x}$ dan $\mathrm{y}$ yang berbeda-beda namun antara satu fungsi keanggotaan denga fungsi keanggotaan yang lain mempunyai bagian range yang sama sehingga grafik menunjukkan adanya perpotongan diantara ke 3 fungsi keanggotaan tersebut.

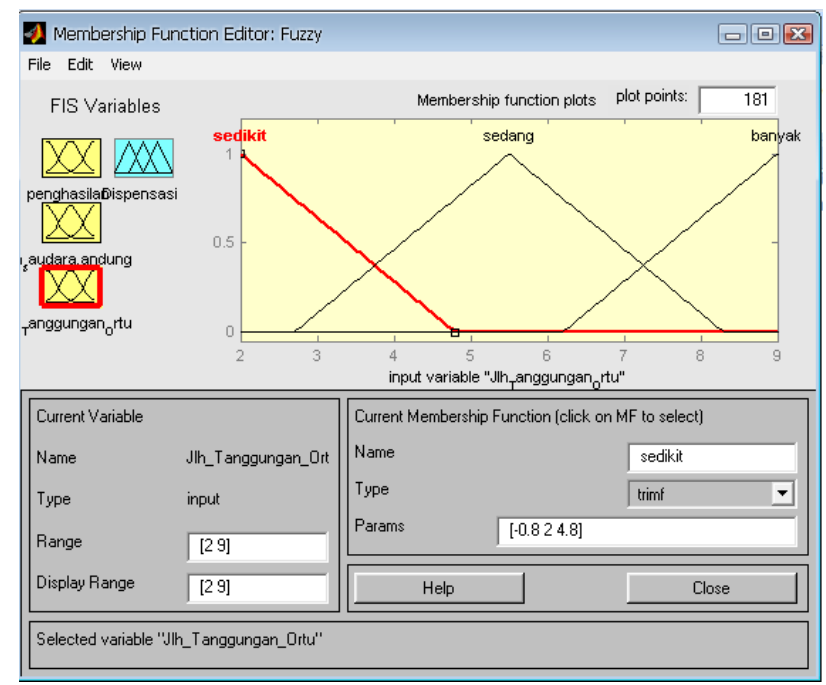

Gambar 4. Fungsi Keanggotaan Input Variabel Jumlah Tanggungan orang tua

Pada gambar di atas dapat dilihat bahwa untuk variabel jumlah tanggungan orang tua mempunyai 3 fungsi keanggotaan yakni sedikit, sedang dan banyak. Dimana jika dilihat dari grafik, maka ketiga fungsi keanggotaan tersebut mempunyai nilai $\mathrm{x}$ dan $\mathrm{y}$ yang berbeda-beda namun antara satu fungsi keanggotaan denga fungsi keanggotaan yang lain mempunyai bagian range yang sama sehingga grafik menunjukkan adanya perpotongan diantara ke 3 fungsi keanggotaan tersebut.

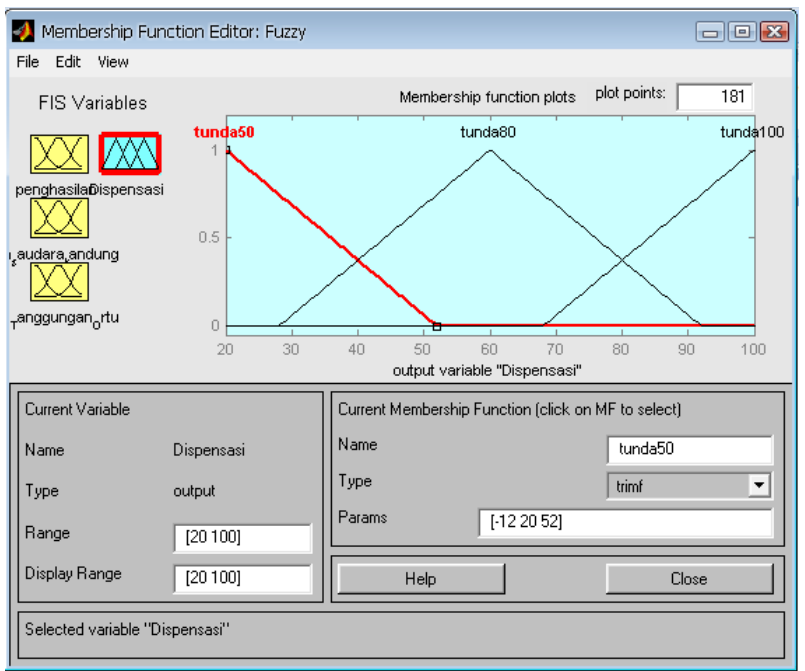

Gambar 5. Design output variabel Dispensasi 
Pada gambar di atas dapat dilihat bahwa untuk variabel output yakni dispensasi mempunyai 3 fungsi keanggotaan yakni tunda 50, tunda 80 dan tunda 100. Dimana jika dilihat dari grafik, maka ketiga fungsi keanggotaan tersebut mempunyai nilai $\mathrm{x}$ dan $\mathrm{y}$ yang berbeda-beda namun antara satu fungsi keanggotaan denga fungsi keanggotaan yang lain mempunyai bagian range yang sama sehingga grafik menunjukkan adanya perpotongan diantara ke 3 fungsi keanggotaan tersebut.

\section{c. Pembentukan Aturan Logika Fuzzy}

Dalam penelitian ini, dimodelkan 3 variabel dengan masing-masing 3 himpunan fuzzy, maka dapat diperoleh 27 kombinasi aturan (rule) logika fuzzy, yakni:

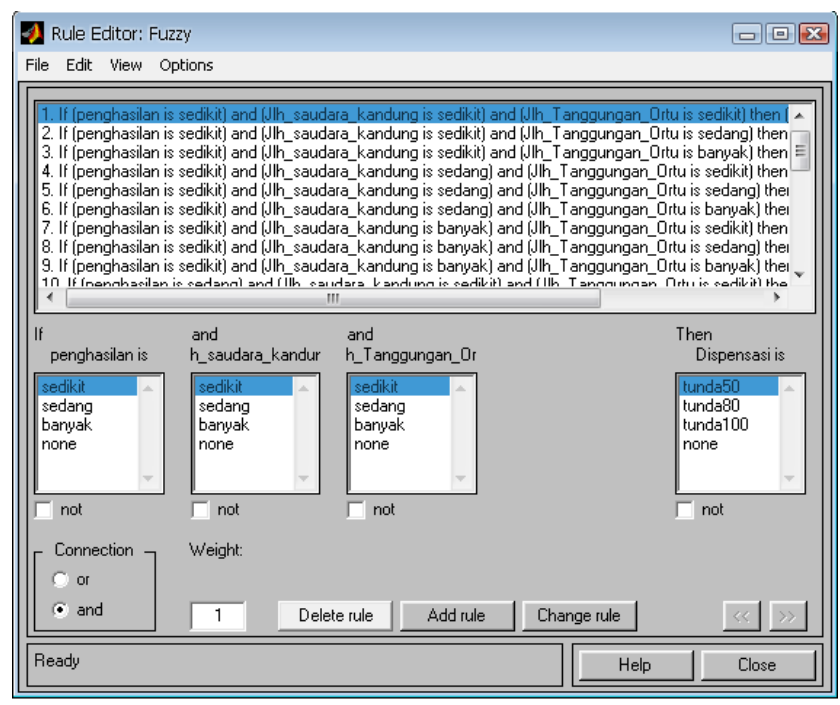

Gambar 6. Rule Editor untuk ijin dispensasi pembayaran uang kuliah

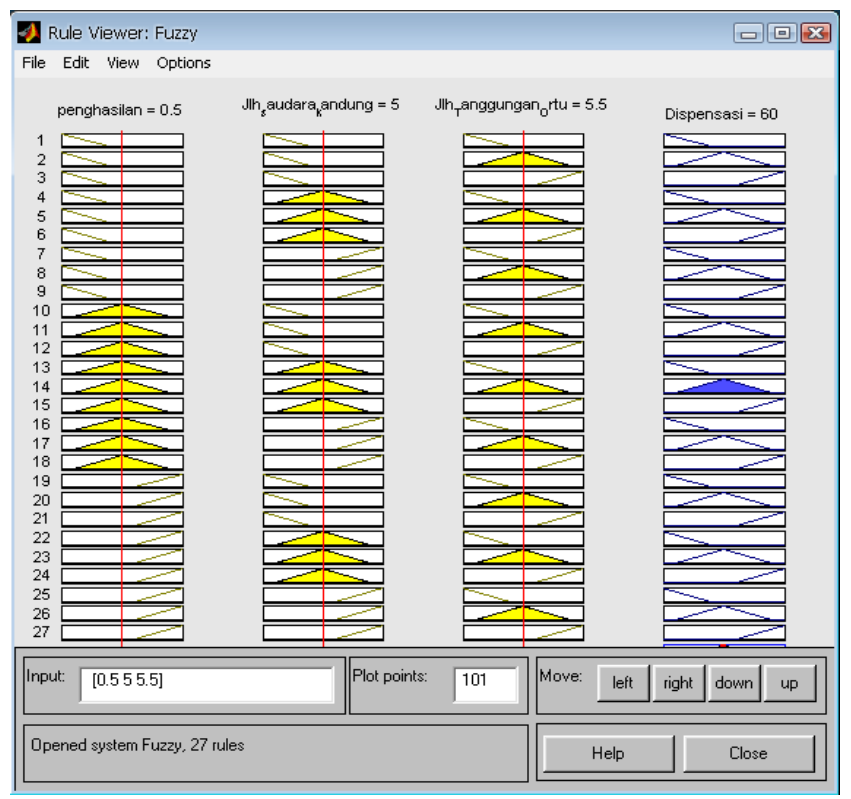

Gambar 7. Rule viewer untuk ijin dispensasi pembayaran uang kuliah 
Pada gambar di atas ditunjukkan bahwa 3 variabel input yakni penghasilan, jumlah saudara kandung dan jumlah tanggungan orang tua dari hasil input rule logika fuzzy, telah diperoleh hasil output dispensasi. Untuk mengetahui keterkaitan antara variabel-variabel input dengan variabel output, dapat dilihat dari suface viewer pada gambar berikut:

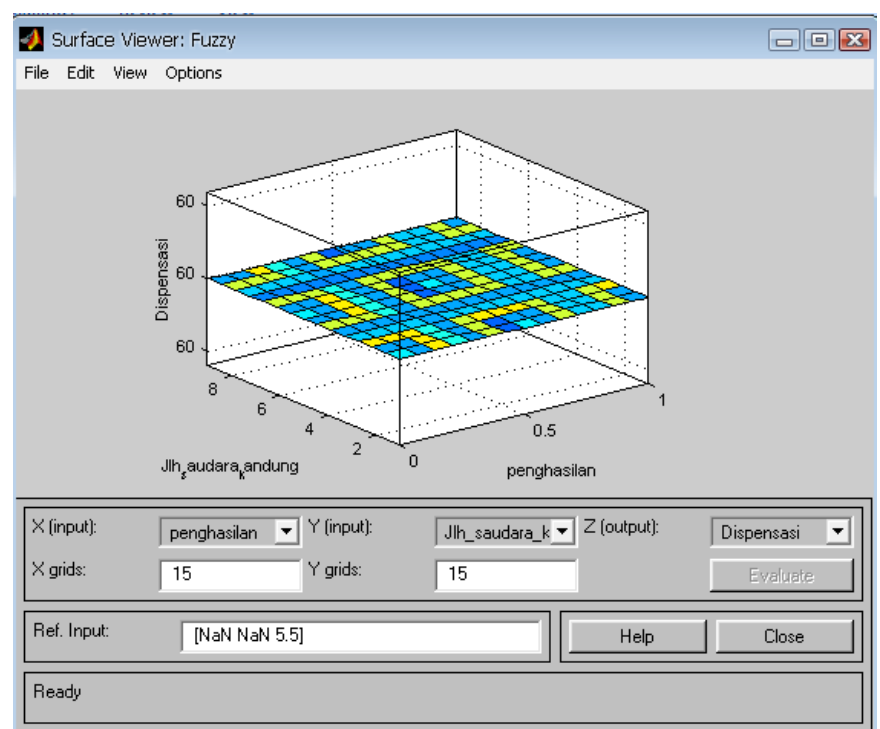

Gambar 8. Surface viewer untuk ijin dispensasi pembayaran uang kuliah

\subsection{Hasil dan Luaran yang dicapai}

\subsubsection{Pengujian dan Analisa}

Untuk menguji sistem inferensi fuzzy dicari beberapa contoh mahasiswa. Kemudian diinputkan pada rule viewer matlab seperti di bawah ini:

Tabel 2. Contoh data mahasiswa

\begin{tabular}{|c|c|c|c|c|c|}
\hline NO & NIM & NAMA & PENGHASILAN & $\begin{array}{c}\text { JLH SAUDARA } \\
\text { KANDUNG }\end{array}$ & $\begin{array}{c}\text { JLH TANGGUNGAN } \\
\text { ORTU }\end{array}$ \\
\hline 1 & 20140103001 & Budi & 0.4 & 1 & 2 \\
\hline 2 & 20140103002 & Astuti & 0.6 & 3 & 5 \\
\hline 3 & 20140103003 & Fima & 0.2 & 2 & 4 \\
\hline 4 & 20140103004 & Lili & 0 & 8 & 2 \\
\hline 5 & 20140103005 & Emma & 1 & 9 & 9 \\
\hline
\end{tabular}




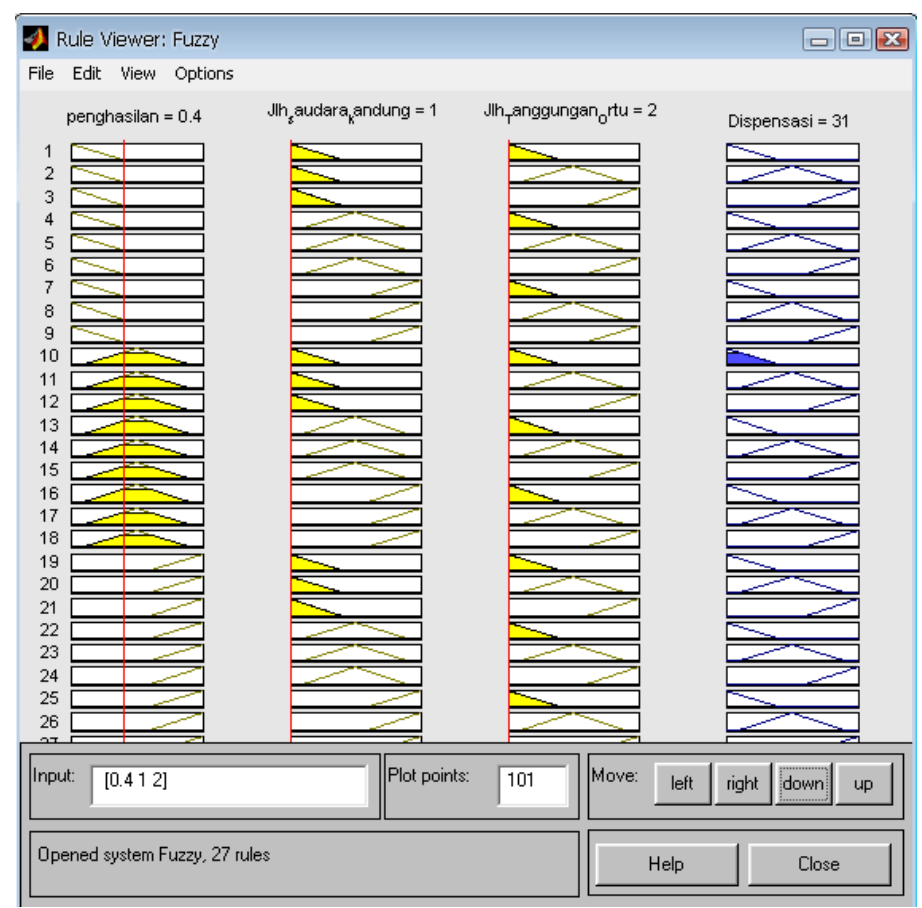

Gambar 9. Hasil pengujian dengan rule viewer

Dari data rekomendasi di atas dapat diketahui bahwa semakin besar/tinggi nilai dispensasi yang diperoleh oleh seorang mahasiswa, maka semakin besar pula nilai dispensasi yang akan diterima oleh mahasiswa tersebut. Itu semua tergantung dari ke tiga variabel input nya.

\section{SIMPULAN}

Dari tahapan-tahapan yang telah dilakukan pada penelitian ini, maka dapat disimpulkan bahwa:

1) Logika Fuzzy dapat digunakan untuk model pengambilan keputusan yang bersifat ragu-ragu (samar) kedalam bentuk tegas (crisp). Dalam hal ini dapat memberikan keputusan tentang pemberian besar dispensasi uang kuliah yang diberikan Institusi kepada mahasiswa nya

2) Sistem yang telah dirancang dapat diimplementasikan oleh pihak manajemen. Sehingga membantu pihak manajemen dalam memberikan keputusan terkait ijin pemberian dispensasi pembayaran uang kuliah.

\section{KONTRIBUSI RISET}

Penelitian ini memberikan solusi kepada pihak manajemen untuk dapat menentukan ijin dispensasi pembayaran uang kuliah kepada mahasiswa/I yang mempunyai masalah dengan keadaan ekonominya. Rekomendasi ini berdasarkan prosedur dan bukan semata - mata berdasarkan insting (perasaan) kasihan ataupun alasan lain nya terkait dengan ijin dispensasi pembayaran uang kuliah. Hal ini sangat lah efektif dalam pengambilan keputusan yang nantinya akan dilakukan oleh pihak manajemen karena semua pengabilan keputusan berdasarkan aturan dan prosedur yang berlaku. Tidak semata-mata karena alasan 
kedekatan, kasihan atau yang lain-lain. Penelitian ini akan memberikan sebuah rekomendasi baru kepada pihak manajemen yang sebelumnya belum pernah ada terkait dengan ijin dispensasi pembayaran uang kuliah. Dan semuanya akan bermuara pada satu tujuan, yakni asas keadilan dan taat prosedur

\section{DAFTAR PUSTAKA}

[1] Kusumadewi, Sri; Purnomo, Hari, Aplikasi logika Fuzzy untuk pendukung keputusan, Graha Ilmu, 2013.

[2] Kusumadewi, Sri; Hartati, Sri; Harjoko, Agus; Wardoyo, Retantyo, Fuzzy Multi-Attribute Decision Making (MADM), Graha Ilmu, 2006.

[3] Kusuma Dewi, Sistem pengambilan keputusan untuk penentuan ijin penundaan pembayaran SPI menggunakan Fuzzy logic.

[4] Sri Kusumadewi, Analisis dan Desain sistem Fuzzy menggunakan toolbox Matlab, Graha Ilmu, 2002.

[5] Poningsih, "Fuzzy Query Database untuk system pendukung keputusan yang cerdas", Jurnal Sains Komputer dan Informatika, Vol. 1, Nomor. 1, AMIK Tunas Bangsa, Pematangsiantar, 107118, Maret 2017.

[6] M. Safii, "Sistem Pendukung Keputusan Penerima Beasiswa PPA dan BBM Menggunakan metode Simple Additive Weighting (SAW)", Jurnal Riset Sistem Informasi dan Teknik Informatika, vol.2, No.1, pp 75-83, 2017. 